This item was submitted to Loughborough's Research Repository by the author.

Items in Figshare are protected by copyright, with all rights reserved, unless otherwise indicated.

\title{
Television news, narrative conventions and national imagination
}

PLEASE CITE THE PUBLISHED VERSION

PUBLISHER

(C) SAGE Publications

VERSION

AM (Accepted Manuscript)

LICENCE

CC BY-NC-ND 4.0

REPOSITORY RECORD

Mihelj, Sabina, Veronika Bajt, and Milos Pankov. 2019. "Television News, Narrative Conventions and National Imagination". figshare. https://hdl.handle.net/2134/5046. 
Date: 31 May 2008

Version accepted for publication

\title{
Paper for DISCOURSE \& COMMUNICATION
}

Title of paper: TELEVISION NEWS, NARRATIVE CONVENTIONS AND NATIONAL IMAGINATION

Authors: Sabina Mihelj, Veronika Bajt and Miloš Pankov

\section{ABSTRACT AND KEYWORDS}

\begin{abstract}
By and large, contemporary news stories are stories about a particular nation, told to an audience that is seen and addressed in national terms. However, the understanding of the exact ways in which national imagination becomes engrained in the narrative conventions of news reporting is still rather limited, in particular when it comes to audiovisual genres. This article aims to fill a part of this blank by examining the links between national imagination and the narrative conventions of television news. Building on existing debates about different modes of news reporting, the article distinguishes two distinct sets of narrative conventions at work in television news: one typically found in routine reporting, the other characteristic of crisis and celebratory reporting. It is argued that each of these two sets of conventions is tied to a different form of nationalism, and normally arises in a different political climate. Links between national imagination and narrative conventions vary accordingly. To demonstrate this, the article provides a comparative analysis of narrative structures in selected samples of television news bulletins broadcast in the early 1990s in the Socialist Federal Republic of Yugoslavia. The concluding section reflects on the external validity of the chosen case study and surveys supportive evidence from four other relevant cases, drawn from Britain and Israel.
\end{abstract}

Keywords: narrative, news genres, television, nationalism, journalistic conventions, routine reporting, crisis reporting, celebratory reporting 


\section{TELEVISION NEWS, NARRATIVE CONVENTIONS AND NATIONAL IMAGINATION}

\section{Introduction}

Over the past few decades, the appreciation of narrative qualities of news genres has become well established among media and communication scholars (e.g. Schudson 1982, 2005, Bird and Dardenne 1983, Ellis 1992 [1982], Lule 2001; Ytreberg 2001; Dunn 2005). Although the presence of narrative structures outside of fiction continues to arouse suspicion, few would disagree with the description of journalists as 'professional story-tellers of our age' (Bell 1991: 147). While dealing with facts and following the professional rules of objective reporting, journalists also engage in particular forms of narration, thereby connecting events into a meaningful totality. These forms of narration draw on a shared supply of narrative devices and plots instantly recognizable to both news-makers and their audiences. However, although perceived as self-evident and unproblematic, the use of these devices is hardly neutral. A particular narrative structure not only 'gives form' to an otherwise chaotic and incomprehensible reality; it also imposes in-built assumptions about the nature of the political process and the role of journalism. For example, the conventions of analytical, non-partisan reporting characteristic of modern-day U.S. journalism are embedded in the perception of the political process as a matter of skilful management, and in the understanding of journalists as expert analysts of political events (Schudson 1982). In contrast, the conventions of partisan reporting typical of Italian journalism in the early 1980s were tied to a polarized political system organized around party politics, and to the notion of journalists as partisans of a particular political cause (Hallin and Mancini 1984).

Another key set of assumptions ingrained into the narrative conventions of news reporting is based on national imagination. In the modern world, being a member of a nation appears as an indispensable attribute of humanity. According to Gellner's (1983: 6) witty comparison, a person without a nation is almost like a person without a nose and two ears: not inconceivable, but almost inevitably regarded as deficient. The link between news narratives and national imagination cannot be posited in quite such a dramatic way, yet its existence is hard to disprove. Thanks to the influence of 
Benedict Anderson's (1983) work, it has become widely accepted that the narrative forms characteristic of modern newspapers had played a crucial role in the early rise and spread of nationalism. Michael Billig's (1995) concept of banal nationalism brought a crucial addendum to Anderson's theory by sensitizing us to the workings of a myriad of routine practices that serve as banal reminders of the nation. Inspired by Billig's work, several more recent studies have looked at the largely unnoticed conventions of representation that support the reproduction of nationalism in contemporary forms of newspaper news, including the use of deictic expressions, frequent references to 'the nation', and the division of news into domestic and foreign (e.g. Yumul and Özkırımlı 2000; Law 2001; Rosie et al. 2004). Although these studies do not explicitly focus on narrative conventions, the characteristics of newspaper reporting they explore can be regarded as attributes of narrative structure.

However, when looking at factual genres in audiovisual media, existing literature provides far fewer clues. This may come as a surprise, particularly given the long and growing record of publications that are drawing on Anderson's theory to examine the links between nationhood and radio, television or film (among the most recent are Douglas 2004; Abu-Lughod 2005; Blandford 2007; Castelló 2007; Dhoest 2007 and Buonanno 2008). Nevertheless, sustained examinations of intersections between national imagination and narrative structures remain limited primarily to studies of fictional genres, in particular films, soap operas, and dramas. In contrast, empirical examinations of national narratives in factual genres are rare (e.g. Jacobs 1996; Kitley 2000: 186-212; Ashuri 2005). This article aims to fill a part of this blank by examining the links between national imagination and the narrative conventions of television news. The next section provides a brief overview of some of the theories of nationalism and national identity that address the role of narration. After that, the article reviews existing debates about narrative conventions in news genres, and identifies two distinct sets of such conventions: one found in routine reporting, the other characteristic of crisis and celebratory reporting. It is argued that each of these two sets of conventions is tied to a different form of nationalism, and normally arises in a different political climate. Links between national imagination and narrative conventions vary accordingly. To demonstrate this, the article provides a comparative 
analysis of narrative structures in selected samples of television news bulletins broadcast in the early 1990s in the Socialist Federal Republic of Yugoslavia. ${ }^{1}$

\section{Narrative and the Nation}

The most recent wave of theorizing about nationalism, usually dubbed as postmodernist or constructivist (Smith 1998: 129-130; Lawrence 2005: 202-206), is particularly susceptible to the conceptualization of nationalism in relation to narratives. Instead of understanding nationalism as a particular type of political movement or political ideology, constructivist theories see it primarily as a form of discourse or a system of cultural representations, and frequently emphasize the role of narratives in the reproduction of nationalism (e.g. Anderson 1983; Bhabha 1990; Özkırıml 2005). Occasionally, nationalism itself is defined as a kind of narrative. Umut Özkırımlı (2005: 179) thus sees nationalism as a 'metanarrative or discourse' which exists beyond the particular narratives of individual nations, and is characterized by a specific combination of spatial, temporal, symbolic and everyday dimensions. National identity is often described in a similar way: as an entity that has no existence outside representation, but should be seen as 'a narrative of the self [...] the story we tell about the self in order to know who we are' (Hall 1996 [1991]: 246), or as 'a discursive construct [...] made up of specifically constructed nation-identity narratives' (Cillia et al. 1999: 155). Narratives therefore not only endow particular events with meaning, thus helping us understand and make sense of the social world, but also serve as tools of identity construction (Hart 1996). By locating themselves or being located within a narrative - usually a narrative that is not of their own making human beings acquire a particular social identity (Somers 1994).

This is not to say that other approaches to nationalism have nothing to say about national narratives. However, they are rarely concerned with their particular forms and structure, but focus almost exclusively on their broader functions and ties with the broader social, political or economic context. By and large, modernist theories (e.g.

\footnotetext{
${ }^{1}$ Materials analysed in this article have been collected and transcribed in the frame of the research project 'Spinning out of Control', funded by the Norwegian Research Council (grant reference no. 174860). The authors would like to express thanks to Radio-Television Serbia and Radio-Television Slovenia for providing access to all the archival materials needed for this project. Thanks are due also to Nedin Mutić for his help with transcriptions.
} 
Gellner 1983; Breuilly 1993 [1982]) are interested in the way national narratives usually referred to as 'myths' - contribute to the perception of nations as timeless entities rather than products of modernization. On the other hand, ethno-symbolists (e.g. Smith 1986, 1999) are concerned with the role of national myths in contributing to the persistence of national identities, as well as in securing the links with premodern collective attachments. In addressing these issues, neither modernists nor ethno-symbolists are really interested in the precise forms of national narratives, or in their variation across different modes and genres of representation. Instead, they tend to view any closer engagement with texts, narratives and representations with suspicion, and associate it with a 'postmodern' abandonment of broader sociological debates (e.g. Smith 1998: 141-142; Breuilly 2002: 81-82; Hearn 2006).

Although constructivist analyses of nationalism are indeed often guilty of such charges, this is not necessarily so. It is equally possible to find studies that marry detailed analysis of nationalist representations to an examination of the broader political, social and economic contexts. In fact, Anderson's (1983) seminal study provides just such an example: it not only examines the particular forms and genres of early modern imagination, but also ties them to a particular mode of production and distribution of the printed world, namely print capitalism. A similarly complex, multilayered examination is of course well beyond the scope of a single journal article. Nevertheless, in order to avoid the dangers potentially inherent in a constructivist approach, this article moves beyond an exclusive focus on narrative structures of media texts, and considers their links with the political context as well as with the elite attitudes towards reported events. Are national narratives present in each and every news bulletin, or does that vary with respect to the political context and the type of event reported? Is it possible to identify structural patterns that link different narrative patterns of national imagination to specific types of political contexts and events? By engaging with these questions, the article follows the arguments of those who have warned against the tendency of narrative analysis to focus only on the text itself (Kozloff 1992 [1987]), and emphasized the need for paying attention not only to multiple forms, but also to the diverse functions narratives play in the context of everyday life (Lucaites and Condit 1985).

\section{Television News and National Narratives}


In one of the earliest book-length studies of television, John Ellis (1992 [1982]) suggested that all television programmes are characterized by a segmented narrative form. Rather than providing one coherent narrative, television offers an open-ended sequence of narrative segments, which are internally coherent, yet not necessarily directly connected to other segments of the programme. Instead, the various segments are organised into open-ended series that occur regularly on an hourly, daily or weekly basis. This form, argues Ellis, is characteristic of both fictional and nonfictional television genres, and he cites the news bulletin as 'the first true use of the open-ended series format [...] endlessly updating events and never synthesising them' (ibid.: 145). However, Ellis' emphasis on the lack of narrative coherence in news bulletins may have been exaggerated. According to Paul Weaver (1975), television news is in fact much more coherent and unified than newspaper news narratives. Unlike the daily newspaper, which normally offers a mishmash of disconnected news stories, 'the TV news program tends to present a single unified interpretation of the day's events as a whole and to construe periods of time as having a single defining movement, action or mood' (ibid.: 85).

Nevertheless, the narrative plot of television news remains much less continuous than that of films, novels or soap operas. The narrative coherence of images is particularly low, and the shortness of the average news story, combined with the need to incorporate the work of exposition into the story, inevitably imposes restrictions on the choice of narrative devices (Corner 1999: 54-55). These constraints largely result from the principle of the 'inverted pyramid', which requires news stories to start with a summary of key information, followed further details in decreasing order of significance. The result of this is that news stories, especially 'hard news' stories, normally lack elements of narrative structure characteristic of fictional genres, for example causal relationships, a double chronology, and typical elements of the dramatic structure, in particular closure and resolution (Dunn 2005: 145-146). Other characteristics of television news that differentiate them from fictional stories have to do with established conventions of objectivity, and serve to convey an image of professionalism and authority of presenters and journalists. These include a neutral, emotionally disengaged vocal delivery, a serious tone, formal dressing, a direct and dialogic mode of address, as well as the prevalence of third-person narration and 
external focalisation, i.e. focalisation from a seemingly neutral point outside the narrative, which is not associated with any character involved in the narrative (Allan 1999: 99-101; Dunn 2005: 147-151).

At first sight, such conventions leave little room for national imagination. Following Schudson's (2003: 177-193) typology of news reporting, the professional conventions of routine reporting are tied primarily to the Habermasian vision of the audience as a rational public, not to the Andersonian vision of an imagined community. Such news stories are meant to provide the material for a rational public debate, not for identitybuilding, and are therefore not narrative-driven. However, the above-mentioned Weaver's (1975) analysis reminds us that television news always displays a certain level of narrative coherence. Arguably, this coherence relies on national imagination. To explain this, it is worth recalling Benedict Anderson's (1983: 32-36) arguments about the links between newspaper stories and the imagined community of a nation. A key source of these links, contends Anderson, lies in 'calendrical coincidence', namely in the fact that all stories in a particular newspaper relate to events that happened on the same day, and concern members of the same imagined community. An additional basis of imagined links can be found in print capitalism, namely in the specific mode of production and distribution which establishes a particular relationship between the newspaper and the market of its readers. This relationship gives rise to an 'extraordinary mass ceremony': the nearly simultaneous consumption of the newspaper by thousands or even millions of readers, who all share an awareness of each-other as members of the same community, without ever meeting in person.

It seems reasonable to suggest that these imagined connections will have their counterpart also in television news programmes, and more specifically in the narrative conventions of television news. Contrary to Schudson's arguments, the professional conventions characteristic of television news appear to fit rather neatly with the imagined links underpinned by the calendrical coincidence of news events and the particular logic of television production. First, the calendrical coincidence, and the associated assumption that all events reported are somehow connected to members of the same imagined community, provide and ideal basis for the relative narrative coherence characteristic of television news noted by Weaver. A typical news bulletin 
can therefore be seen as a narrative about events that happened to a particular imagined community on a given day, or that are deemed important enough for all members of that community to know. And second, the direct, dialogic mode of address characteristic of television news bulletin can be seen as a manifestation of the imagined link that ties the bulletin to its intended market. This mode of address typically involves speaking straight to the camera, as if talking to each individual viewer, and relies on dialogical, personalised forms of address such as 'Dear viewers, good evening'. This creates the impression of a dialogue and of an intimate link between the institutional voice of the television and the imagined viewer, and helps create a fictive 'we' embracing the newsreader(s) and the viewers (Allan 1999: 100). It is easy to see how this fictive 'we' can be used to refer to the imagined community of a nation, and therefore function as a banal reminder of national belonging (Billug 1995).

However, we should be weary of jumping to conclusions too quickly. As the case study presented in the following section will demonstrate, television news narratives do not necessarily explicitly define the fictive 'we' as a national we. In a similar vein, events reported in a news bulletin are not normally unequivocally presented as events happening to a particular nation. Although clearly compatible with national imagination, such banal reminders can in fact accommodate many competing and even incompatible definitions of collective identity, which allows the exact content and boundaries of the fictive 'we' to remain fuzzy and flexible. Sometimes, newsreaders and journalists may use the 'we' simply to refer to themselves as journalists, or to the media institution they represent (e.g. Hallin and Mancini 1984: 839). These observations are, in fact, in line with one of the criticisms occasionally levelled at Anderson's theory - namely that it is based on a tacit assumption that the imagined community fostered by the newspaper will necessarily be a national one (see Breuilly 1985; Schlesinger 1991: 156; Rosie et al. 2004).

Not all the television news, however, are that ambiguous when referring to the fictive 'we'. In a context of war or in moments of collective celebration accompanying major national holidays, the fictive 'we' is filled with more explicitly national content, and the various events reported are unambiguously presented as events happening to a particular nation. War reporting, for example, regularly abandons the professional 
conventions of analytical and balanced coverage. Instead, journalists adopt a patriotic stance and organize their narratives around the basic conflict between 'us' and 'them', between 'our nation' and its enemies (Hallin 1986; Allan 1999: 172-180). This kind of reporting is normally adopted in situations of elite consensus, i.e. when events fall outside of the sphere of legitimate controversy (Hallin 1986). The implied audience of such reporting is the nation, and news serves primarily to provide the raw materials for identity-building rather than rational public debate (Schudson 2003: 188). Such reporting is also much more 'story-like' than the usual, analytical and non-partisan kind of reporting. It diverges from the conventions of the inverted pyramid, and draws on narrative devices typical of fictional narratives (ibid.).

The following sections elaborate these arguments further by suggesting additional elements of narrative structure and national imagination that vary depending on the particular mode of reporting employed, such as the use of deictic expressions, narrative voice and focalization, and the type of actors. Table 1 summarizes the key characteristics of the two modes of reporting, provides a list of particular narrative conventions characteristic of each of them, and indicates how these conventions relate to different types of nationalism and national imagination. The next section demonstrates the usefulness of this model with the help of a case study. 


\begin{tabular}{|c|c|c|c|}
\hline & & ROUTINE REPORTING & CRISIS/CELEBRATORY REPORTING \\
\hline \multirow{2}{*}{ CONTEXT } & Political context & Peace/ routine events & War/ extraordinary events \\
\hline & Elite attitudes & $\begin{array}{l}\text { Elite dissensus - events seen as falling into the } \\
\text { sphere of legitimate controversy }\end{array}$ & $\begin{array}{l}\text { Elite consensus - events seen as falling into the sphere of } \\
\text { consensus or deviance }\end{array}$ \\
\hline $\begin{array}{l}\text { TYPE OF } \\
\text { NATIONALISM }\end{array}$ & & $\begin{array}{l}\text { Banal nationalism - the world of nations as the } \\
\text { invisible frame of reporting }\end{array}$ & $\begin{array}{l}\text { Hot nationalism - nations as key forces and actors in } \\
\text { reported events }\end{array}$ \\
\hline \multirow{6}{*}{$\begin{array}{l}\text { NARRATIVE } \\
\text { CONVENTIONS }\end{array}$} & Implied audience & A (national) public, divided over particular issues & A nation, united in attitudes on particular issues \\
\hline & Use of deictic expressions & $\begin{array}{l}\text { Mostly to refer to the journalists/the media } \\
\text { institution. }\end{array}$ & $\begin{array}{l}\text { Often to refer to the imagined national community } \\
\text { including both the journalists and the audience. }\end{array}$ \\
\hline & $\begin{array}{l}\text { Narrative voice and } \\
\text { focalization }\end{array}$ & Third-person narration, external focalisation & $\begin{array}{l}\text { Frequent first-person narration from the point of view of } \\
\text { the national 'we', multiple (external and internal) } \\
\text { focalisation }\end{array}$ \\
\hline & Key actors & $\begin{array}{l}\text { Individuals and/or groups that form part of the } \\
\text { nation but do not share the same opinions }\end{array}$ & $\begin{array}{l}\text { Nations and/or their representatives sharing the same } \\
\text { opinions. The national 'we' (embracing the journalists and } \\
\text { their addressees) as one of these actors. }\end{array}$ \\
\hline & $\begin{array}{l}\text { Narrative coherence of the } \\
\text { bulletin }\end{array}$ & $\begin{array}{l}\text { Open-ended sequence of loosely connected } \\
\text { segments }\end{array}$ & $\begin{array}{l}\text { Narrative connecting the segments into a unified whole - } \\
\text { a narrative about the nation }\end{array}$ \\
\hline & Dramatic structure & $\begin{array}{l}\text { Inverted pyramid structure. Dramatic structure } \\
\text { weak, elements of classic dramatic structure } \\
\text { missing. }\end{array}$ & $\begin{array}{l}\text { Dramatic structure more prominent, especially at the level } \\
\text { of the narrative connecting the individual news items. }\end{array}$ \\
\hline
\end{tabular}

Table 1: Modes of reporting, narrative conventions and national imagination 


\section{The Case Study}

The case study focuses on prime-time TV news bulletins broadcast in the socialist Yugoslavia in the period from June 21 to July 16, 1991. Materials come from two TV stations, located in two different Yugoslav republics: TV Ljubljana in the Republic of Slovenia (TVL) and TV Belgrade (TVB) in the Republic of Serbia. The period includes two key events that, from the point of view of the political elites in both republics, fell outside of the scope of legitimate controversy. The first one was Slovenia's Declaration of Independence, issued on June 25, which was treated as a major national celebratory event on the Slovenian side, but fell into the realm of deviance for the Serbian political mainstream. The second major event, or rather a series of events, was the so-called 'Ten-Day War' that started in Slovenia on June 27, when the Yugoslav army made an attempt to keep the country together and maintain federal control over Slovenia's borders. The Slovenian government at the time anticipated such developments and mobilised its territorial defence units, arguing that the Yugoslav army intervention is in fact a hostile attack of a foreign army on a sovereign state. After international intervention a cease-fire was agreed, and following prolonged negotiations the Yugoslav Army withdrew from Slovenia, and the epicentre of Yugoslav wars moved into Croatia and soon after that into Bosnia. In both Slovenia and Serbia, the political mainstream treated the conflict in a broadly consensual manner, although the exact narratives and their implied explanations and evaluations were completely divergent. On the whole, however, in both republics both events fell outside of the scope of legitimate controversy. Following the arguments developed in the previous section, we can therefore expect that their television coverage will display the characteristic narrative elements common to crisis and celebratory reporting, identified in Table 1. As the following sections demonstrate, the analysis confirmed these expectations.

\section{Implied Audience, Deictic Expressions, Narrative Voice and Focalisation}

Outside of the two key events, newsreaders and journalists rarely used explicit deictic references to an imagined community embracing both the narrators and their addressees. Such use of deixis was limited primarily to accessed voices, i.e. to the voices of the interviewees, especially politicians. When journalists themselves used 
deictic expressions such as 'we' or 'our', they were most often referring to themselves and their colleagues, and to the media institution they were representing. The following opening of a bulletin broadcast by TVL after the cessation of hostilities provides a typical example:

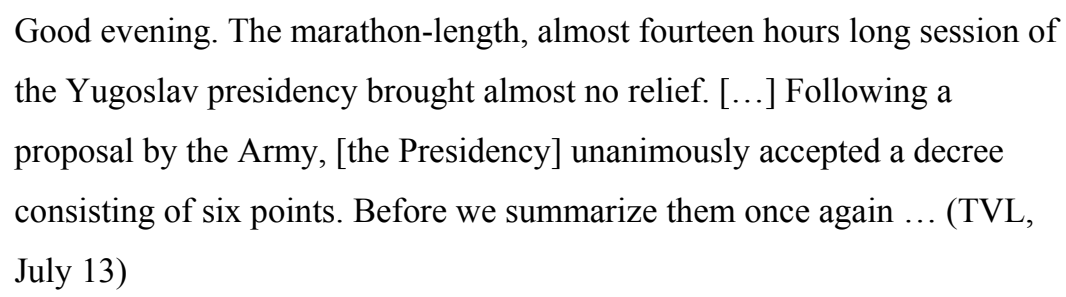

Clearly, the 'we' that is about to provide a summary of the decree does not embrace all members of the imagined community addressed by the bulletin. Instead, the deixis serves to establish a clear division between 'us, the journalists' and 'you, the viewing public'. The newsreader is not talking in the name of any imagined national community, but represents the institution of television which is bringing the latest news of the day to its viewers. At the same time, such deictic positioning also detaches the newsreaders and journalists from the events they are reporting, establishes them as external observers, and necessitates the adoption of third-person narration and external focalization. This does not in itself preclude or abolish the imagined link that ties the journalists, their viewers, as well as the actors of events being reported, into the same imagined community. However, this link is normally not explicitly foregrounded in the bulletin itself by means of deictic expressions, nor does it serve as the basis for a shared point of view on events that are being reported. Quite to the contrary: the use of deixis outlined above helps establish the television as the professional, analytical, non-partisan reporter of events. This does not mean that the reporting in this period was entirely balanced. Yet for most of the time, reporters did at the very least acknowledge the existence of diverse opinions among members of the same public, and reported about them from the position of an external, thirdperson narrator. Or, to put it differently: at this point, topics were still falling within the scope of legitimate controversy, and their treatment was therefore closer to the professional, detached mode typical of routine reporting.

In contrast, the reporting during the war and immediately before and during the declaration of independence in Slovenia was permeated by deictic expressions which were unambiguously tied to a particular nation or state. The news-anchors and 
journalists of TVB for example spoke about 'us, the Yugoslavs' (TVB, June 29) and ‘our Yugoslav problem' (TVB, June 29), and used expressions such as 'our people', 'our citizens' and 'our country' in a way that made clear they were referring to Yugoslavs and Yugoslavia. The following opening of a news bulletin broadcast a few days before Slovenia's declaration of independence provides a characteristic example:

\footnotetext{
Dear viewers, good evening. What will happen to Yugoslavia tomorrow? Several inhabitants of our country are raising this question, as do virtually all world news agencies and foreign journalists accredited in our country. [...] The country of Yugoslavs today provides plenty of reasons for such dramatic questions. (TVB, June 21)
}

By mentioning 'our country' a few moments after directly addressing the audience ('Dear viewers, good evening.'), the newsreader clearly situates himself and his audience into the same imagined community. Furthermore, his mention of 'Yugoslavia' in the second sentence and 'the country of Yugoslavs' in the fourth sentence leaves little doubt as to which country this imagined community belongs to.

The presenters of TVL were using deictic expressions in much the same way, yet tied them to a different imagined community and country: to Slovenians and Slovenia. In the following excerpt, the news-presenter uses a deixis - 'we' - to include himself into the imagined community celebrating Slovenia's independence. The explicit mention of Slovenia and its independence, along with the reference to the Slovenian capital (Ljubljana) as the focus of celebrations, clarifies which nation and which country the 'we' is referring to:

\footnotetext{
Good evening. Yesterday evening, Slovenia became autonomous and independent. Today we are celebrating: in some places already the whole day, while in the evening, joy and pride will burst out everywhere. The main celebrations will take place in Ljubljana. The fact that Yugoslavia already reacted to our yesterday's decision should not make the evening any less pleasant, primarily because we have expected it. (TVL, June 26)
}

The above excerpt can also serve as an example of how the national 'we' provided the explicit basis for internal focalization in news narratives. Not only was the newsreader discursively positioning himself and his audience into the same national community, at the same time, he also started narrating the events of the day from that position, i.e. from the point of view of 'us, the nation'. Most importantly, this nation was presented 
as one of the key actors of the narrative: celebrating, expecting a reaction to its celebration, and remaining in a joyful mood despite the reaction. The other key actor in the same narrative is identified as 'Yugoslavia', and is quite unambiguously cast into the role of a villain who can endanger 'our' celebrations. At the other end of the federation, TVB was using the same narrative devices, but identified the key actors in a diametrically opposite way: the imagined 'we' telling the story was associated with Yugoslavia, while the villain was 'Slovenia'.

It is worth noting that such use of deictic expressions and internal focalization assumes that everyone among 'us' is sharing the same attitude towards Slovenia's independence and towards the reaction of the Yugoslav Army. The opening lines of the TVL bulletin quoted above allow no scope for members of 'us' who may not want to join in the celebrations of independence - as the newsreader states, "joy and pride will burst out everywhere'. Similar patterns can be discerned in TVB's reporting in the same period. Clearly, both televisions perceived their audiences and themselves primarily as part of an imagined national community in the sense defined by Benedict Anderson: as a group of people tied by 'a deep, horizontal comradeship' (2007 [1983]: 7) which exists above and beyond any inequality, exploitation, or internal dissent.

This, however, does not mean that the deictic expressions and explicit 'flaggings' of either the Slovenian or the Yugoslav nation left no room for divergent interpretations. Although the scope for diversity was significantly narrower than in routine reporting, it was not abolished entirely. If we return again to the uses of deictic expressions in the last excerpt - the 'we' who are celebrating - we can note that the exact nature of the relationship between 'us' and the state remains ambiguous. For example, does the 'we' include everyone permanently residing in the given territorial unit, regardless of ethnic affiliation? Is it equally open both to former communists as well as to those leaning towards the political right? Arguably, it is not a coincidence that the particular journalistic use of deictic expressions and national flags in this period avoids addressing these questions. These were, at the time, the most divisive questions among the respective political elites in each of the republics, and any attempt to address them could have undermined the appeal to national unity. Even in the period of crisis and celebration, 'the nation' therefore continued to function as a polyvalent 
symbol with multiple meanings. As such, it was amenable to a wide variety of disparate uses, and had the ability to mobilise different audiences who thought that they understood it in the same way (cf. Verdery 1996: 227). Indeed, our analysis confirms that the utility of national deixis, as well as national 'flags' more broadly, lies precisely in their ambiguity, and in their associated ability 'to simultaneously carry diverse meanings to different audiences [...] while appearing to address one common audience by virtue of literally using the same words' (Rosie et al. 2004: 454).

\section{Choice of Actors, Narrative Coherence and Dramatic Structure}

As mentioned in the previous section, celebratory and crisis reporting was characterised by a prominent presence of a national 'we', which very often became also a key actor in, as well as narrator of, the events reported. In contrast, the choice of actors in routine reporting was following rather different patterns. Although individual nations and/or national states still featured among the key actors, journalists were deictically detached from them. Also, the majority of actors in fact consisted of named individuals, institutions and groups, such as presidents, parliaments, political parties or state officials. These actors were often seen as representative of the nation or the state, but were not equated with them. A typical opening of a news bulletin therefore looked, in terms of the choice and naming of actors, similar to the following one:

\footnotetext{
Good evening. In Belgrade extraordinary political activity of the highest Yugoslav representatives. First Slobodan Milošević, as the host of the second round of talks between the leaders of Bosnia and Herzegovina, Croatia and Serbia, spoke to the presidents Franjo Tuđman and Alija Izetbegović. Today afternoon, following the initiative of Slovenia and Croatia, Ante Marković spoke to Milan Kučan, Franjo Tuđman, Janez Drnovšek and Stjepan Mesić. [...] Later in the bulletin we are providing a full report from the talk between Milošević, Izetbegović and Tuđman. (TVB, June 19)
}

The opening mentions two collective actors, 'Slovenia' and 'Croatia', as well as a long list of individuals representing the respective Yugoslav republics and federal institutions. The narrator avoids using any deictic expressions that would explicitly 
position him closer to one or another of the named actors. Instead, he establishes a clear division between himself as a journalist and representative of the television ('we are providing a full report') and the named actors participating in the narrative. We could therefore argue that the opening follows the typical inverted pyramid structure, starting with key information on the who (the named actors), what (talks), when (today, in the afternoon) and where (in Belgrade) of the major events of the day, before turning to further details and other events. However, even this rather dry account is not without a certain level of narrative coherence. The two key events mentioned share a link, highlighted in the second sentence: they are both part of the 'extraordinary political activity of the highest Yugoslav representatives'. Other bulletins broadcast in this period displayed a similar structure, and a similar array of actors and information. In most cases, the news-anchor went beyond the mere recounting of individual events of the day and identified a particular mood, theme or attitude that was common to all or at least the key events.

Still, this level of narrative coherence appears rather low when compared to a typical narrative provided by the news-anchors during the war or immediately before the declaration of independence. This increased level of coherence often went hand-inhand with the prominence of national deixis and internal focalisation: the events of the day were explicitly presented as events happening to 'us, the nation', and were tied into an overarching national narrative. The opening of the news bulletin broadcast by TVL towards the end of the violent confrontations provides a telling example.

\footnotetext{
Good evening. Today was a peaceful day as well, and life is returning to our streets again. This is filling us all with hope that what we have lived through in the past days will never happen again. However, things were not particularly peaceful for those who are now trying to settle the situation in Slovenia and Yugoslavia through negotiations and tolerant dialogue.
}

(TVL, July 06)

The first actor mentioned in the excerpt, which at the same time also constitutes the deictic centre and thus the venture point for internal focalisation, is identified as 'us all', and embraces both the narrator and his addressees. Other actors - 'those who are now trying to settle the situation' - are being described from the point of view of 'us', implying that their actions are of some relevance to 'us'. The narrative starts by relating 'our' experiences in the past few days, and situates the efforts of negotiators 
into the same narrative about things relevant to 'us'. Later in the same bulletin, the newsreader resumes the same deictic position on several occasions, situating the various events of the day into the context of the overarching narrative about 'our' suffering and resilience. For example:

\footnotetext{
We have faced several challenges; we have been tormented by problems, natural and other catastrophes. Yet we have always stayed firm, and we still are, since we always relied primarily on ourselves, although friendly neighbourly help kept easing our pain and wounds. This time, solidarity will emerge as well, since the picture of locations where the army horde raged is the same as 46 years ago. Gornja Radgona, one of the worst stricken municipalities, was visited today by the Slovenian parliamentary delegation. (TVL, July 06)
}

Again, the key actor in the narrative is a collective 'we' embracing both the narrator and his addressees, and potentially referring to everyone in the Slovenian nation. Similarly as in the opening sentences, the narrator first recounts 'our' experiences, this time going almost half a century back in time to establish continuity between present and past suffering, resilience and solidarity. In the second step, it turns to the subject of the report - the visit of the parliamentary delegation to one of the towns damaged during the conflicts - and presents it as an integral part of the longer chain of collective experiences.

Internal focalisation from the point of view of 'us, the nation' was not the only device that lent greater coherence to crisis and celebratory bulletins. A closely related narrative strategy consisted of positioning the nation and/or the state as a key actor of the events. A characteristic example can be found in the news bulletin broadcast by TVB in early July:

Dear viewers. Yugoslavia is experiencing its most dramatic moments since the Second World War. At the start of the Daily Bulletin, member of the Supreme Command of the Armed Forces of Yugoslavia, Colonel General Blagoje Adžić, speaks to you. (TVB, July 02)

This dramatic opening clearly identifies 'Yugoslavia' as the key actor - in fact a victim - of the events of the day. The narrative of current events is put into a longer historic context, stretching back to the Second World War, which helps emphasize the gravity of the situation. As befits the atmosphere, the opening is followed by a lengthy 
direct address delivered by an army general. The remainder of the bulletin brings several news items that reinforce the opening narrative: reports about violent clashes in Slovenia, diplomatic efforts to stop the conflicts, parents of Yugoslav Army recruits storming the Serbian parliament and requesting their sons to be sent home. The narratives provided by the news-anchors of TVL followed the same pattern, yet understandably the roles of the main heroes and villains, victims and perpetrators, are reversed.

Another thing to note is that the national narratives weaving together the individual news items were not brought to a resolution or closure within each individual bulletin. Instead, they typically built upon the narratives provided in previous days, and extended to forthcoming bulletins. These overarching narratives, stretching over several days and even weeks, displayed elements of a classic dramatic structure typical of fictional genres. This can be demonstrated by looking at a selection of openings of news bulletins broadcast by the same television:

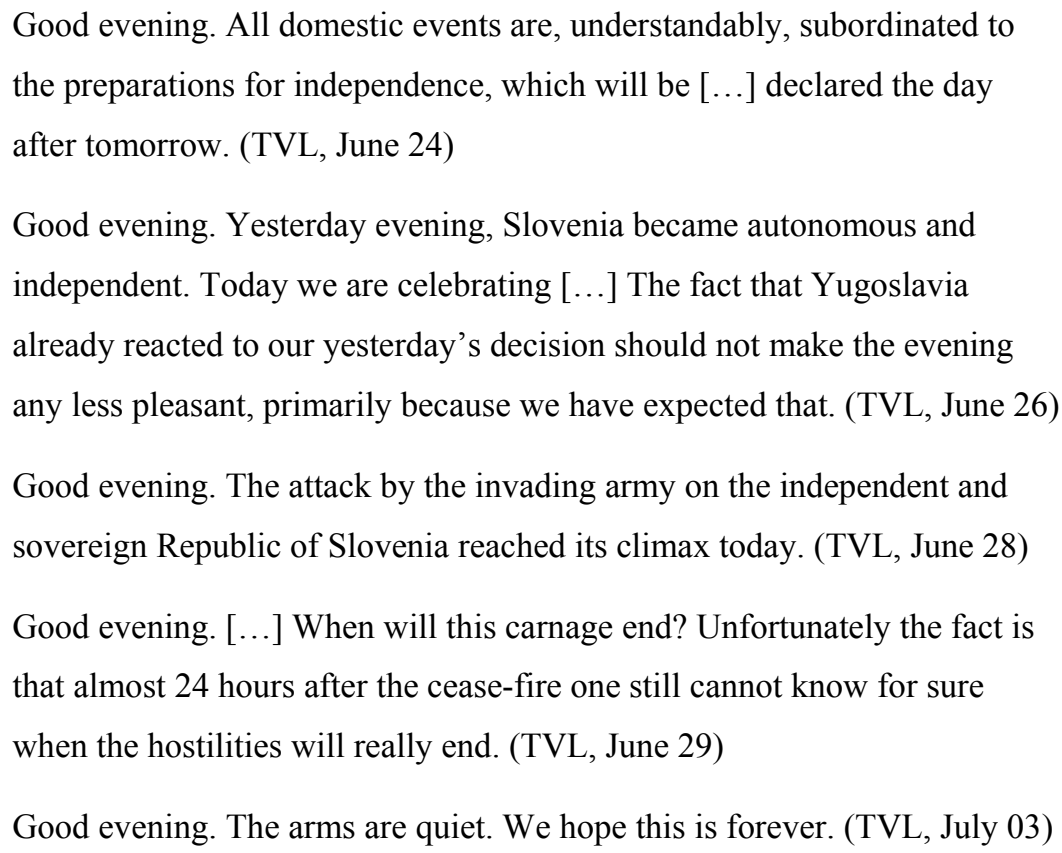

The openings are telling an unfolding story about the nation, country, or 'us'. The narrative starts with a relative equilibrium and expectation of change, i.e. Slovenia's independence (June 24), which is followed by a complication or disequilibrium brought by the reaction of 'Yugoslavia' (June 26). Then follows a dramatic climax in the form of the 'attack by the invading army' (June 28), a longing for closure (June 29), and finally a re-establishment of equilibrium (July 03). The story-line continues 
from one bulletin to the next, with newsreaders frequently referring to events of the past days or speculating about the future. Additional coherence is brought by the continuity of actors (individual nations, the army etc.). From this point of view, the narrative structure of news bulletins in this period resembled that of a television series, transforming the news bulletin into a grand 'soap-opera' about the national family - though one with real rather than fictional consequences.

\section{Conclusions and Reflections on the General Validity of the Case Study}

Our case study suggests that we should distinguish two key forms of national narration in television news. On the one hand, in a context of elite dissensus and routine reporting, explicit national narratives are normally absent. Newsreaders and journalists typically use third-person narration and external focalization, identify themselves only with other journalists and the media institution, and detach themselves both from their audience and from the events reported. This does not in itself preclude or abolish the imagined link that ties the journalists and their viewers into the same imagined community. After all, such narration is still underpinned by the assumption that all the events reported are somehow related to one another, and of relevance to the same audience. However, these links are not explicitly presented as national, and are simultaneously compatible with a broad range of different identity narratives, be they national or of another kind. As such, these devices allow for the coexistence of competing definitions of reality and belonging, which are crucial for the functioning of a public sphere, while at the same time maintaining a basic overarching commonality.

In contrast, crisis and celebratory reporting emerging in situations of elite consensus is permeated by deictic expressions that are unambiguously tied to a particular nation or national state. The newsreaders are discursively positioning themselves and their audience into the same national community, and are using internal focalization, narrating the events from the point of view of 'us, the nation'. Another typical element of this mode or reporting is the increased level of narrative coherence: the individual news items are woven together into an overarching national narrative. However, these narratives are not brought to a resolution or closure within each individual news bulletin. Instead, they build upon the narratives provided in previous 
days, and extend to forthcoming news programmes. The daily bulletins are therefore telling an unfolding dramatic story about the nation, starting with an initial equilibrium, followed by a disruption, climax, and then gradual resolution and closure. In such a context, 'the nation' continues to function as a polyvalent symbol with multiple meanings, yet the scope for diversity is significantly narrower than in routine reporting. Instead of allowing for the coexistence of competing definitions of reality, such narratives serve to delegitimate and silence any form of internal dissent.

One may be tempted to object the general validity of these conclusions by arguing that the chosen case study is rather extreme. Indeed, in many ways, the materials have not been chosen on a random basis, and may not necessarily represent typical examples of routine and celebratory or crisis reporting. Although the case study fits the key categories of reporting as defined in Table 1, several other contextual factors make it highly likely that the analysed coverage would conform to expected patterns. First, similarly as their counterparts elsewhere in the region, Yugoslav postcommunist elites treated the media in much the same way as their communist predecessors: as instruments of control belonging to the ruling party (see e.g. Veljanovski 2002). At the same time, journalists and editors were often complicit in sustaining such attitudes, treating democratically elected representatives with virtually unlimited trust. Although the elites never achieved full control over the media in respective republics, alternative voices were confined strictly to media with limited audience reach. Television stations such as TV Ljubljana and TV Belgrade were particularly prone to governmental control, and their positions were closely tied to the political mainstream (Bašić Hrvatin 1997). Last but not least, the events in question were part and parcel of nation-state building processes, and as such almost inevitably went hand in hand with nationalist discourses.

Due to all these additional contextual factors, the selected case should best be treated as a strategically chosen case rather than as a representative case. However, this should not be seen as a drawback. Quite the opposite is the case: randomly chosen cases often provide little information, and prevent us from clarifying the key structures and causes of a particular phenomenon under study (Flyvbjerg 2006: 229). Although the case examined above does not allow us to establish the frequency of particular narrative patterns in television reporting at large, it does provide grounds 
for concluding that our proposed model has not been falsified. To demonstrate that the model is indeed valid also on a larger scale, and in cases where the context is less favourable to the thesis, one would need to conduct further case studies. These should ideally extend below cases of war reporting, and include examinations of crisis and celebratory reporting in an otherwise generally peaceful context, such as for example the television reporting on immigration, demonstrations and conflicts abroad, or the coverage of major national holidays or sports contests. Furthermore, although this article focuses exclusively on television coverage, the general claims may be at least partially applicable to other media channels and genres, depending on their exact ties with the political realm, and on the particularities of their narrative conventions.

Of course there is no shortage of empirical studies dealing with potentially relevant cases. However, only very few focus simultaneously and systematically on both the political context and the exact forms of national narration and journalistic conventions, as well as changes over time and the differences and similarities between routine and crisis/celebratory reporting. Evidence drawn from existing research is therefore inevitably rather patchy, yet nevertheless worth pointing to. The study that comes closest to the approach adopted in this article - in the sense that it focuses explicitly on the relationship between nationalism and the professional conventions of journalistic reporting - is the study of the Israeli media coverage of the violent clashes between the Israeli Arabs and the police in early October 2000, conducted by Eyal Zandberg and Motti Neiger (2005). This case provides an important testing ground for our general model because it involves a case of limited violence rather than a fullscale military confrontation. According to the authors, Israeli journalists initially abandoned their usual, neutral stance, and instead reported the events from an explicitly ethnonational point of view, positioning themselves alongside the Israeli police and the Jewish majority, and against Israeli Arabs. This indicates that the shift from routine to crisis reporting also coincided with the shift from a civic-nationalist frame, which potentially included all Israeli citizens regardless of ethnic affiliation, to an explicitly ethnonationalist frame, which excluded Arabs from the national 'we'. After the violence stopped, and after the talks between the Israeli Arab leaders and the Prime Minister had started, the tone of coverage changed. It moved closer to a more balanced reporting, and hence away from an explicitly ethnonationalist frame towards a more inclusive, civic one. 
Since Zandberg and Neiger do not distinguish between 'hot' and banal forms of nationalism, and use qualitative content analysis rather than an explicitly narrative or discursive approach, it is not possible to establish whether these shifts coincided with changes in patterns of narrative conventions. Nevertheless, the correspondence between the shifts in the general framing of events on the one hand, and the changes in the political sphere on the other hand, does suggest that this case conforms to the general patterns observed in the Yugoslav example. It is also worth noting that Zandberg and Neiger found compatible trends not only in television reporting, but also in newspaper coverage. However, while the tabloid newspaper Yedioth Ahronoth was eager to adopt the patriotic style of crisis reporting, the positioning of the elite newspaper Ha'aretz was somewhat more ambiguous. Although the newspaper maintained the ethnonationalist frame, its occasional deviations from the patriotic tone were enough to prompt a part of the audience to cancel their subscription to the newspaper (ibid.: 138). These variations suggest that different types of media are not all equally susceptible to shifts in the political realm and the corresponding pressures to join the patriotic drive. Whether and how that varies with the political affiliations of different media institutions, their ownership structures, professional regulatory mechanisms, or other factors, remains open to investigation.

Also instructive is the dynamics of the relationship between the $\mathrm{BBC}$ and British politics during the Falklands War in 1982, especially given the Corporation's quasiautonomous status vis-à-vis both political and economic influence. As the study of the Glasgow University Media Group (1985: 13-14) revealed, the BBC initially covered the conflict in a 'balanced' way, providing views from different 'authoritative' sources within the British society, including oppositional ones, and refusing to use the deictic expressions such as 'us' and 'we' when referring to the British. This suggests that in the initial phase of the conflict, the $\mathrm{BBC}$ was following the narrative conventions of routine reporting, discursively distancing itself from both the viewing public and the interviewees, and acting as a fairly non-partisan reporter. At this point, individual Conservative and Labour MPs were still openly voicing their opposition to the war, which suggest that the conflict remained at least partly within the scope of legitimate controversy. Still, a banal national frame remained in place: the oppositional voices were, after all, coming from within the British society. 
As the conflict developed, even this limited impartiality came under attack. Shortly after the controversial Panorama programme broadcast on 10 May, which featured Conservative and Labour opposition to the war, the BBC shifted closer to the government position. One of its evening news programmes even included a shot of a group of people singing 'There'll always be an England' (ibid.: 14). This may indicate that the $\mathrm{BBC}$ switched to crisis reporting, addressing and representing the audience as a nation, united in its attitudes towards the war. Dissenting voices among the elites were still present, yet were not being expressed through normal, official channels channels the $\mathrm{BBC}$ would usually rely on when covering political disagreements in the country (ibid.: 24-25). Although the relationship between the BBC and the political realm at the time was less tight than the relationship between TVL and TVB and the respective republican governments in Slovenia and Serbia, we therefore see a similar pattern of shifts in narrative conventions and national imagination emerging in both cases.

Both of the above are of course examples involving crisis reporting, and therefore provide little indication of the general applicability of our model in cases of celebratory reporting. To compensate for that, we will briefly examine two case studies of celebratory media events (Dayan and Katz 1992), both taken from contemporary Britain and limited to the press: an examination of the coverage of the football match between Germany and England during Euro 2000 (Bishop and Jaworski 2003), and a study of the reporting of the Queen's Golden Jubilee in 2002 (Wardle and West 2004). The first case is unfortunately focussed on 'hot' nationalism only, and provides no insight into the relationship between the media and the political realm at the time, yet it clearly demonstrates that the reporters adopted many of the narrative conventions characteristic of the celebratory mode, identified in table 1.

For example, they frequently included themselves, the English footballers and the intended readership in the same national 'we', as well as adopted internal focalization, narrating the game from the point of view of 'us, the nation'. This is clearly visible in the titles of articles quoted by the authors, such as 'So can we do it?' and 'It's our turn' (quoted in Bishop and Jaworski 2003: 251). Both titles feature deictic expressions that unambiguously embrace both the narrator and the England team. In 
both cases, the key actor, namely the England team, features as the representative of the whole nation, or, as the authors put it, stands in a metonymic relationship vis-à-vis the nation. This metonymic relationship also implies that everyone among 'us' shares the same celebratory spirit. The implied audience is therefore constructed as a nation rather than a public, united in its perceptions of the game. Last but not least, if we examine the quoted excerpts from articles published on different days, we can also notice that they form a part of an overarching national narrative, spanning over several days. Similarly as in the case of the Yugoslav war coverage, this overarching narrative displays elements of the classic dramatic structure. For example, the titles of articles quoted above, appearing on the day of the game, signal expectation, while the titles of articles published after the game, such as e.g. 'We beat 'em!' (quoted in ibid.: 251), complete the narrative by recounting the dramatic climax.

The study of the media coverage of the Golden Jubilee reveals similar trends. However, unlike Bishop and Jaworski, Wardle and West also focus on fluctuations in the intensity of national discourse over time, and on differences between various types of newspapers. They argue that the press across the board started discussing the event from a relatively neutral and even overtly sceptical position, but then gradually embraced a more celebratory stance. After it became obvious that the jubilee turned out to be a success, even the most anti-jubilee press, such as The Guardian, had to admit their negative predictions were wrong. Yet as the authors note, the success of the jubilee did not lead to a complete reversal of the newspaper's attitude. Furthermore, at least in the extensive quote provided in the article, there is no evidence of The Guardian adopting internal focalization, or discursively joining a homogenous, joyous national 'we':

\footnotetext{
We need to face up to the facts. . . This has undoubtedly been a great weekend for the House of Windsor and for the Queen in particular. It would not be true to say that their popularity has never been greater, but it is undoubtedly true that this is one of the best mornings the monarchy has ever had. (quoted in Wardle and West 2004: 209-10)
}

In the above excerpt, the 'we' does not embrace the Royal Family, but appears to be limited to The Guardian and its ideal readers - at least those who share its anti-jubilee stance. The monarchy may well have experienced 'one of [its] best mornings', yet it is 
not presented as a part of 'us'. This deictic positioning is markedly different from the one used in an article published by the tabloid The Mirror on the same day:

For hours before the arrival of the fairytale carriage, the crowds here had talked about how 'real' their Queen felt to them today. The triumphant Party at the Palace had shown her to be accessible. Fun-loving. One of us. [...] One woman in front of me leapt in the air and flailed her arms around her head. Her husband confided that the last time he'd witnessed this, they'd been at Woodstock. (quoted in ibid.: 209)

The event is described from an intra-diegetic viewpoint: the narrator is using a firstperson perspective ('us', 'me') and is deictically positioning himself within the same diegetic continuum as the one inhabited by the actors of the event ('the crowds here', 'woman in front of $m e$ '). He is also enthusiastically proclaiming that the Queen became '[o]ne of us', thereby including the Queen, himself and the crowd around him into the same imagined community. Since the authors used a thematic analysis rather than a discursive or narrative one, it is impossible to establish how representative these examples are. Yet they do at the very least confirm that future studies of narrative conventions and national imagination in the media will need to take into account differences between various media types and genres.

The evidence drawn from the fours studies is of course merely indicative, yet it does provide further support for the general theoretical claims developed in the article. It also suggests that carefully designed comparative studies in this area, which combine systematic discourse analysis with a careful consideration of contextual factors, could produce interesting results. Last but not least, such comparative research would also help counter the fragmentation of mass communication research into separate strands of text-based and sociologically informed analysis, and hence further general theoretical debates in the field across disciplinary divides. 


\section{References}

Abu-Lughod, L. (2005) Dramas of Nationhood: The Politics of Television in Egypt. Chicago and London: Chicago University Press.

Allan, S. (1999) News Culture. Buckingham: Open University Press.

Anderson, B. (1991 [1983]) Imagined Communities: Reflections on the Origins and Spread of Nationalism ( $2^{\text {nd }}$ Edition). London and New York: Verso.

Ashuri, T. (2005) 'The Nation Remembers: National Identity and Shared Memory in Television Documentaries', Nations and Nationalism 11(3): 423-442.

Bašić Hrvatin, S. (1997) 'The Role of the Media in the Transition', in Hafner-Fink, D. and Robbins, J. R. (eds.) Making a New Nation: Formation of Slovenia. Aldershot: Ashgate, pp. 267-277.

Bell, A. (1991) The Language of News Media. Oxford and Cambridge, MA: Blackwell Publishers.

Bhabha, H. K. (1990) 'Introduction', in Bhaba, H. K. (ed.) (1990) Nation and Narration. London: Routledge, pp. 1-7.

Billig, M. (1995) Banal Nationalism. London, Thousand Oaks and New Delhi: Sage. Bird, E. and Dardenne, R.W. (1983) 'Myth, Chronicle, and Story: Exploring the Narrative Qualities of News', in Carey, J. W. (ed.) Media, Myths and Narratives: Television and the Press. Newsbury Park, New York, New Delhi: Sage, pp. 67-86.

Bishop, H., and Jaworski, A. (2003) “"We Beat 'em"”: Nationalism and the Hegemony of Homogeneity in the British Press Reportage of Germany versus England during Euro 2000', Discourse \& Society 14(3): 243-271.

Blandford, S. (2007) Film, Drama and the Break-up of Britain. Bristol: Intellect Books.

Breuilly, J. (1993 [1982]) Nationalism and the State, $2^{\text {nd }}$ edition. Chicago: The University of Chicago Press.

(1985) 'Reflections on Nationalism', Philosophy of the Social Sciences 15: $65-75$.

(2002) 'Historian and the Nation', in Burke, Peter (ed.) History and

Historians in the Twentieth Century. Oxford: Oxford University Press, pp. 5587. 
Buonanno, M. (2008) The Age of Television: Experiences and Theories. Bristol: Intellect.

Castelló, E. (2007) 'The Production of Television Fiction and Nation Building: The Catalan Case', European Journal of Communication 22(1): 49-68.

De Cillia, R., Reisigl, M. and Wodak, R. (1999) 'The Discursive Construction of National Identities', Discourse \& Society 10(2): 149-173.

Corner, J. (1999) Critical Ideas in Television Studies. Oxford: Oxford University Press.

Dayan, D., and Katz, E. (1992) Media Events: The Live Broadcasting of History. Cambridge, Mass: Harvard University Press.

Dhoest, A. (2007) 'Identifying with the Nation: Viewer Memories of Flemish TV Fiction', European Journal of Cultural Studies 10(1): 55-73.

Douglas, S. J. (2004) Radio and the American Imagination. Minneapolis: Minnesota University Press.

Dunn, A. (2005) 'Television News as Narrative', in Fulton, H., with Huisman, R, Murphet, J. and Dunn, A. (2005) Narrative and Media. Cambridge: Cambridge University Press, pp. 140-152.

Ellis, J. (1992 [1982]) Visible Fictions. London and New York: Routldge.

Flyvbjerg, B. (2006) 'Five Misunderstandings about Case-Study Research', Qualitative Inquiry 12(2): 219-245.

Gellner, E. (1983) Nations and Nationalism. Oxford: Basil Blackwell.

Glasgow University Media Group (1985) War and Peace News. Milton Keynes and Philadelphia: Open University Press.

Hall, Stuart (1996 [1991]) 'Ethnicity: Identity and Difference', in Ely, Geoff and Ronald Grigor Suny (eds.) Becoming National: A Reader. Oxford and New York: Oxford University Press.

Hallin, D. C. (1986) The 'Uncensored War': The Media and Vietnam. Berkeley, Los Angeles and London: University of California Press.

Hallin, D. C. and Mancini, P. (1984) 'Speaking of the President: Political Structure and Representational Form in U.S. and Italian Television News', Theory and Society 13(6): 829-850.

Hart, Janet (1996) New Voices in the Nation: Women and the Greek Resistance, 19411961. Ithaca and London: Cornell University Press. 
Hearn, J. (2006) Rethinking Nationalism: A Critical Introduction. Basingstoke:

Palgrave Macmillan.

Jacobs, R. N. (1996) 'Civil Society and Crisis: Culture, Discourse, and the Rodney

King Beating', The American Journal of Sociology 101(5): 1238-1272.

Kitley, P. (2000) Television, Nation and Culture in Indonesia. Ohio: Ohio University Center for International Studies.

Kozloff, S. (1992 [1987]) 'Narrative Theory and Television', in Stuart, Allan (ed.)

Channels of Discourse, Reassembled: Television and Contemporary Criticism, $2^{\text {nd }}$ edition. London: Routledge, pp. 67-100.

Law, A. (2001) 'Near and Far: Banal National Identity and the Press in Scotland', Media, Culture \& Society 23: 299-317.

Lawrence, P. (2005) Nationalism: History and Theory. Harlow: Pearson Education.

Lucaites, J. L. and Condit, C. M. (1985) 'Re-constructing Narrative Theory: A

Functional Perspective', Journal of Communication 35(4): 90-108.

Lule, J. (2001) Daily News, Eternal Stories: The Mythological Role of Journalism.

New York and London: The Guilford Press.

Özkırıml, U. (2005) Contemporary Debates on Nationalism: A Critical Engagement, Basingstoke: Palgrave Macmillan.

Rosie, M., Petersoo, P., MacInnes, J., Condor, S., and Kennedy, J. (2004) 'Nation Speaking unto Nation: Newspapers and National Identity in the Devolved UK', The Sociological Review 52(4): 437-458.

Schlesinger, P. (1991) Media, State and Nation. London: Sage.

Schudson, M. (1982) 'The Politics of Narrative Form: The Emergence of News

Conventions in Print and Television', Daedalus 111 (4): 97-112. (2003) The Sociology of News. New York and London: W.W. Norton \& Company. (2005) 'News as Stories' in Rothenbulher, E. W. and Coman, M. (eds.)

Media Anthropology. London, Thousand Oaks and New Delhi: Sage, pp. 121128.

Smith, A. D. (1986) The Ethnic Origins of Nations. Oxford: Basil Blackwells. (1999) Myths and Memories of the Nation. Oxford and New York:

Oxford University Press. (1998) Nationalism and Modernism: A Critical Survey of Recent

Theories of Nations and Nationalism. London and New York: Routledge. 
Somers, M. R. (1994) 'The Narrative Constitution of Identity: A Relational and Network Approach', Theory and Society 23: 605-649.

Veljanovski, R. (2002) 'Zaokret elektronskih medija', in Popov, N. (ed.) Srpska strana rata: Trauma i katarza $u$ istorijskom pamćenju - Part II, $2^{\text {nd }}$ edition. Belgrade: Samizdat Free B92, pp. 178-204.

Verdery, K. (1996) 'Wither "Nation" and "Nationalism," in Balakrishnan, G. (ed.) Mapping the Nation. London and New York: Verso, pp. 226-234.

Ytreberg, E. (2001) 'Moving out of the Inverted Paradigm', Journalism Studies 2 (3): 357-371.

Yumul, A. and Özkırıml, U. (2000) 'Reproducing the Nation: "Banal Nationalism" in the Turkish Press', Media, Culture and Society 22(6): 787-804.

Wardle, C. and West, E. (2004) 'The Press as Agents of Nationalism in the Queen's Golden Jubilee: How British Newspapers Celebrated a Media Event', European Journal of Communication 19(2): 195-214.

Weaver, P. H. (1975) 'Newspaper News and Television News', in Television as a Social Force: New Approaches to TV Criticism. London and New York: Praeger Publishers, pp. 81-94.

Zandberg, E. and Neiger, M. (2005) 'Between the Nation and the Profession: Journalists as Members of Contradicting Communities', Media, Culture \& Society 27(1): 131-141. 